\title{
Leveraging Electronic Word of Mouth on TikTok: Somethinc Skin Care Product Innovation to Increase Consumer Purchase Intention
}

\author{
Camelia Hasena $^{\mathrm{a}, *}$, Eko Sakapurnama ${ }^{\mathrm{a}}$ \\ ${ }^{a}$ Departemen Ilmu Administrasi Niaga, Fakultas Ilmu Administrasi, Universitas Indonesia, Depok, Jawa Barat, 16424, Indonesia
}

\begin{abstract}
Social media platforms continually assisting the industry as a media promoter for its customer. This study aims to determine how the influence of electronic word of mouth on TikTok on purchase intention of Somethinc skincare products through brand image. This study uses a quantitative approach with data collected using a survey method. The research instrument used a questionnaire distributed via Google Form. The number of samples in this study were 100 respondents who were TikTok users, knew about, and had never bought Somethinc skincare products. The analysis technique used in this research is simple linear regression. The results of this study indicate that the four hypotheses of this study are accepted. It was concluded that there was an influence between eWOM on TikTok on purchase intention of Somethinc skincare products, the influence between e-WOM on TikTok on Somethinc's brand image, the influence between Somethinc brand image on purchase intention of Somethinc skincare product, and influence between Electronic word of mouth on TikTok. towards purchase intention of Somethinc skincare products through brand image.
\end{abstract}

Keywords: Somethinc, TikTok, electronic word of mouth, brand image, purchase intention

\section{INTRODUCTION}

The development of technology nowadays has grown faster from time to time and continues to increase drastically. The development of the internet is a sign that now the world has entered a period of industrial revolution 4.0. Everything in human life in various fields, both in the economic, social, and other fields has changed thanks to the industrial revolution 4.0. Many of the activities today have been successfully realized by innovators, which these activities had never been imagined to be carried out today. Before entering industrial revolution 4.0, the public could only get access to information or news through limited broadcasts on television networks. However, technological developments and the use of the internet today, it has had a major impact on people's lives.

The presence of the internet has made it easy for communication facilities, learning facilities, and sources of information using various media. One of them is by using social media. Even now, everyone including the Indonesian people has made the internet their primary need. Based on the Global Digital Report 2020, research on the social media platform Hootsuite and

\footnotetext{
* Author in correspondence,

Email address: camelia.hasena@ui.ac.id (Camelia Hasena)
}

the We Are Social media platform, it is stated that around 64\% of Indonesians have access to a connection to the internet. The research states that as of January 2020 in Indonesia there are currently 175.4 million people who are internet users. From the same research, it is stated that Indonesia now has 160 million social media users, where this figure has increased by around $8.1 \%$ or 12 million users when compared to the results of the previous year's research (Dateportal.com, 2020).

Most people today choose to use social media as a means to obtain and exchange information about a product online. One of the new trends that people are now using when using social media to obtain and exchange information about a product online is by using the TikTok application. TikTok itself is a short video-based social media application that relies on creativity. The application made by ByteDance, a company from China in 2016, is now a booming application around the world (Katadata.co.id, 2020). According to data from application research company Sensor Tower, as of August 2020, TikTok has become the most downloaded non-game application worldwide. This data shows a shift in the technology industry (Sensortower.com, 2020). This ByteDance application also has a very rapid development, where in the last three years TikTok has been downloaded more than 2 billion times (Katadata.co.id, 2020).

In addition, according to Sensor Tower, as of August 2020, Indonesia is the country with the most downloads of this application, with Indonesia contributing 11\% of TikTok's total 
downloads (Sensortower.com, 2020). Dina Bhirawa, Head of Marketing for TikTok Indonesia, said that apart from dancing, singing, tutorials, vlogs, fashion, talent, and food content are the most popular types of content on TikTok, content about beauty is equally popular in the application (Ramadhanny, 2019).

Skincare reviews are also a type of review content that is widely liked and often viral on TikTok. The video uploaded by TikTok users under the account name @ kaelynwhitee is an example of viral skincare review content on TikTok. In the video he uploaded, Kaelyn Whitee gave a review of AHA 30\% + BHA 2\% Peeling Solution skincare products from the brand The Ordinary. The product then becomes viral or is widely discussed and is sought after by consumers. Based on information obtained from representatives of The Ordinary, the video uploaded by Kae turned out to be successful in increasing sales of the peeling product so that it sold 52 thousand units in two weeks (Wolipop.detik.com, 2020). Due to the high interest of buyers, this product has also experienced a price increase, from the normal price of IDR 130 thousand to a range of IDR 400 thousand (Beautyjournal.id, 2020).

Cosmetic products are also one of the products that continue to experience increasing purchasing power every year. Based on the 2019 Annual Report from the L'oreal company, every year the global cosmetics market continues to experience growth. Not only that, but skincare is also a business segmentation whose growth continues to increase globally beyond the cosmetics market. In the report, the sharp increase in the skincare market in 2018 was driven by the continued growth in purchasing beauty products online, the development of social networks, and the expansion of the upper-middle class around the world and especially in the Asia Pacific, where consumers have high enthusiasm and broad knowledge. regarding skincare products. It can be seen in the graph above that the growth of the global skincare market in 2018 increased sharply by $9 \%$ and $8 \%$ in 2019, while the cosmetics market increased to $5 \% / 5.5 \%$ (Loreal-finance.com, 2019).

The growth of the cosmetics and skincare industry globally also has an impact on the growth of the cosmetics and skincare industry in Indonesia. The Ministry of Industry noted that there was a cosmetic industry growth of $7 \%$ in 2019 (Kementerian Perindustrian dan Perdagangan, 2020). Research results from SAC Indonesia also said that skincare products were the largest market for cosmetics throughout 2018 (Industri.kontan.co.id, 2019). Various skincare brands in Indonesia are starting to develop rapidly with a strategy of making skincare products with different variants according to the user's skin needs. Telunjuk.com through tempo.co collected skincare sales data in the last month from three giant e-commerce companies in Indonesia, namely Shopee, Bukalapak, and Tokopedia. Quoting data from the Compas Market Insight Dashboard for the period 8 August - 7 September 2020, it noted that there were five skincare products from the best-selling favorite brands from their online sales in the three e-Commerce (Forums and Lists, 2020).

One of the five best-selling skincare brands is the Somethinc brand. Established in March 2019, this brand was founded because it was inspired by consumers who are looking for halalcertified and high-quality skincare products for an active lifestyle.
Somethinc aims to meet the needs of the young and smart generation who are currently very critical in choosing skincare products, not only wanting to look attractive but also paying attention to the importance of using high-quality products at affordable prices. Therefore, Somethinc answers consumer needs by launching skincare products containing clean ingredients that are safe and halal to use, local skincare with international standards, and at affordable prices (Indiemarket.news, 2020). Somethinc, which is known as the local version of The Ordinary, in 2019 also received the title as Best Newcomer Local Brand from Female Daily.

Irene Ursula, Founder of Somethinc, explained that since the establishment of Somethinc, this brand has managed to steal the attention and get a positive response from the public. With a price of 100 thousand rupiahs for a $20 \mathrm{ml}$ size, Somethinc Niacinamide + Beet Serum is one of the best-selling local skincare products, even often sold out and much sought after on online shopping sites (Forums and Lists, 2020). Somethinc which currently has 929 thousand followers on its Instagram account and 211 thousand followers on its TikTok account is one of the skincare brands whose hashtag \#somethinc is the most used hashtag by a skincare brand and has been viewed 107 million times on the TikTok application.

The role of the internet and social media is increasingly being recognized for their influence in driving the growth of the beauty industry. Chief Executive Officer of Social Bella, John Marco Rasjid, said that social media is one of the three fundamental things that have contributed greatly to driving the growth of the beauty industry (Kementerian Perindustrian dan Perdagangan, 2020). Now, many people have used social media as one of their means to obtain and exchange information about a product online. Through the internet and social media, consumers are constantly exposed to the various messages and information that brand owners are trying to convey to encourage and change their attitudes.

One of the trends that consumers are now using to obtain information on a product is to use e-WOM. A survey stated that the majority of consumers assess online opinions as reliable and trustworthy as the brand's website itself (ACNielson, 2007). Rowley (2001) also stated that commercial companies need to organize these online associations rather than relying solely on advertisements posted on the internet. These observations show how strong the potential influence of e-WOM is on the consumer purchasing decision process. This situation can then affect promotional activities to build a brand image into the memory of consumers so that the products offered can be remembered by consumers and increasingly attract consumer buying interest (purchase intention). Technological developments during the 4.0 industrial revolution made the use of eWOM form a brand image and attract consumer buying interest to become an increasingly effective business strategy. Therefore, this research aimed to determine whether consumer buying interest and brand image on Somethinc skincare products were influenced by e-WOM on TikTok. 


\section{LITERATURE STUDY}

\subsection{Electronic Word Of Mouth}

Electronic Word of Mouth is defined by Hennig-Thurau et al. (2004) as a notification, whether positive or negative, where this notification is made using the internet by consumers about a product or company. When consumers want to collect information about a product, consumers often look for reviews or product information online first before making a purchase (Jalilvand and Samiei, 2012). e-WOM has two types of messages for certain groups of people, namely those with strong ties such as family and friends or those with weak ties such as acquaintances whom direct consumers to post and share product messages. Both types of messages provide information on products, services, and experiences and can influence consumer purchase interest and behavior (Brown and Reingen (1987); Wang et al. (2018)).

\subsection{Brand Image}

Brand image or brand image is defined as a representation of consumer perceptions and consumer preferences for brands. This perception is reflected in the various kinds of brand affiliations that are in the minds of consumers. Brand Image is a representation of the overall brand perception which is formed from brand information from past experiences. Brand Image is related to beliefs and attitudes towards brand preferences. Consumers with a positive brand image are more likely to make purchases (Setiadi Nugroho, 2003). Brand image is a brand perception that is explained by existing brand associations and is inherent in the consumer's memory. Thus, a company must be able to create a competitive advantage that can be used as a reason for consumers to choose a particular brand (Keller, 1993).

\subsection{Purchase Intention}

Purchase intention is defined as part of the behavioral component of consumer attitudes. Kinnear (1995) said that purchase interest is a stage where consumers tend to take action before actually making a purchase decision. If consumers decide to buy a certain product, it can be stated that the product has been consumed by the consumer. The purchase decision itself is influenced by the value of the product being evaluated. If consumers feel that the profit is greater than the sacrifices they make to get it, the motivation to buy it will be higher and vice versa. The majority of consumer buying behavior is usually triggered by a large number of external forces such as marketing or environmental impulses.

The hypothesis is prepared based on a literature review on previous studies, so several hypotheses can be formulated for this study, which is as follows:

$H_{1}$ : Electronic Word of Mouth in TikTok has a significant effect on Purchase Intention of Somethinc Skincare Products

$\mathrm{H}_{2}$ : Electronic Word of Mouth on TikTok has a significant effect on Brand Image Somethinc

$\mathrm{H}_{3}$ : Brand Image has a significant effect on Purchase Intention of Somethinc Skincare Products
$\mathrm{H}_{4}$ : Electronic Word of Mouth on TikTok has a significant effect on Purchase Intention of Somethinc Skincare Products through Brand Image

\section{METHOD}

This study uses a quantitative approach that focuses on measurement and sampling design problems because it is deductive in nature, and emphasizes detailed planning for data collection and analysis (Neuman, 2014). This study uses a quantitative approach because it has characteristics, where this study aims to find a cause-and-effect relationship, correlation, evaluation of activities/programs that are objective, structured, and limited. The data to be collected by researchers is divided into two, namely primary data and secondary data. Primary data is obtained by surveying the form of a structured online questionnaire using the help of Google Forms. Respondents can complete a self-administered questionnaire in about 5-10 minutes. Secondary data that is owned can be obtained from literature studies, books, scientific journals, articles, websites, and other literature studies related to this research topic. Secondary data has the aim to help build the formulation of research problems and a theoretical basis by the research model.

In this study, the population was respondents who knew and had never bought Somethinc skincare products and were TikTok users. Then, the researcher used a non-probability sampling technique with a purposive/judgmental type of sampling. Purposive/judgmental sampling is a sampling technique in terms that are limited to certain types of people who can provide the information desired by researchers (Sekaran, 2011).

The criteria for selecting the sample were respondents who were over 18 years old, were users of the TikTok application, and who knew and had never bought skincare products from the Somethinc brand. These criteria were chosen because they are considered capable of answering the research questionnaire well so that they are able to help researchers obtain quality data. In addition, the ideal and representative respondent size should be 100 or larger (Hair, 2014).

Therefore, the researcher took 100 respondents because that number was considered sufficient to represent the population studied. The data collected was then tested for validity and reliability, then analyzed using a linear regression model and a t-test was performed to test the coefficients. Descriptive analysis is used to describe the object under study. The Sobel test is used to test the strength of the indirect effect of the independent variable on the dependent variable through the mediating variable.

\section{FINDINGS AND DISCUSSION}

The distribution of the average value of 100 respondents on the variable electronic word of mouth shows that the indicator of Extraversion / Positive Self-enhancement, namely the desire of consumers to share their consumption experiences to improve their self-image as a smart buyer, has the highest mean value of 4.31. So it can be concluded that the respondents who 
were the subject of this study stated that they strongly agreed that they got information about positive reviews of Somethinc skincare consumers through TikTok because of the high desire of consumers to share their consumption experiences. Then for the statement that has the lowest average value of 3.84 , it is found in the platform assistance indicator, namely consumer confidence in the platform used. Thus, it can be said that even though the information regarding Somethinc skincare review on Tiktok does not directly make consumers believe this information.

The distribution of the average value of 100 respondents on the brand image variable shows that the corporate image indicator which includes the popularity and credibility of Somethinc itself has the highest mean value of 4.30. It can be concluded that the respondents who were the subjects of this study thought that Somethinc had good popularity, reputation, and credibility in producing skincare. Then, the corporate image indicator regarding the company Somethinc network itself in distributing its products so that it can be easily obtained by consumers has the highest mean value of 4.30. It can be concluded that the respondents of this study considered that Somethinc had a good company network in distributing its products. Meanwhile, the user image indicator regarding the association of affiliation that is perceived by consumers to users who use a product or service has the lowest average value with a mean value of 3.82 . It can be concluded that these respondents did not think that using Somethinc skincare could make them confident.

The distribution of the average value of 100 respondents on the purchase intention variable shows that the indicator of transactional interest, which is about the situation when someone has a tendency or interest to buy a product, has the highest mean value of 4.38. So it can be concluded that the respondents who are the subject of this study have an interest in buying Somethinc skincare. Meanwhile, preferential interest is a condition when a person's interest in his main preference for a product has the lowest average value, which is 3.80. It can be concluded that the respondents of this study did not think that they would make Somethinc skincare their first choice of skincare priority. Next, the researcher will explain the research hypothesis testing. The following are the results of hypothesis testing on hypothesis 1 .

The first hypothesis aims to examine the relationship between the Electronic Word of Mouth in TikTok and the Purchase Intention of Somethinc Skincare Products. Based on the results of data processing carried out, the significance value obtained is 0.000 . So it can be concluded that this regression model can be used because it has a significance value below 0.05. For the F value, the value is 59.522 which has a p-value of $\mathrm{xx}$ which is greater than $5 \%$, then $\mathrm{H}$ is rejected and $\mathrm{H}$ is accepted (see Table 1.

These results are in line with the results of the study conducted by Elseidi and El-Baz (2016) that reinforce the view that e-WOM can play a major role in influencing purchasing decisions. In addition, Jalilvand and Samiei (2012) also stated that positive e-WOM has a significant effect and can affect purchase intention. Next, for the result of hypothesis 2 testing, Table 2 shows the results.
The second hypothesis aims to examine the relationship between the Electronic Word of Mouth in TikTok and the Brand Image of Somethinc Skincare Products. Based on the results of data processing carried out, the significance value obtained is 0.000 (see Table 2). It can be concluded that this regression model can be used because it has a significance value below 0.05 . For the $\mathrm{F}$ value, the value is 86,958 . When compared with the F table for this study which has a value of 3.09 which means $\mathrm{F}$ count $i \mathrm{~F}$ table, then $\mathrm{H}$ is rejected and $H_{a} 2$ is accepted. (Jalilvand and Samiei, 2012) also revealed that the interactive published online communication of WOM can have a significant impact on brand image. In addition, Jalilvand and Samiei (2012) in their research also proved that e-WOM is one of the most effective components in influencing brand image. Next, for the result of hypothesis 3 testing, Table 3 shows the results.

The third hypothesis aims to examine the relationship between Brand Image and Purchase Intention of Somethinc Skincare Products. Based on the results of data processing carried out, the significance value obtained is 0.000 . So that this regression model can be used because it has a significance value below 0.05 . For the F value, the value is 118.074 . When compared with the F table for this study which has a value of 3.09 which means $\mathrm{F}$ count $i \mathrm{~F}$ table, then $\mathrm{H}$ is rejected and $H_{a} 3$ is accepted. This is supported by the results of research by Muhammad Aqsath Faza in 2018 which is the basis of this research that brand image has a positive effect on buying interest. Brand Image plays a significant role because it is an indirect tool that can influence consumer buying interest. In addition, Elseidi and El-Baz (2016) revealed that brand image has a strong influence in influencing consumer purchase interest in certain brands. Finally, to test hypothesis 4 , the researcher will also perform a regression test and a Sobel test. Table 4 shows the results.

The fourth hypothesis aims to examine the relationship between the Electronic Word of Mouth in TikTok and the Purchase Intention of Somethinc Skincare Products through the Brand Image. Based on the results of data processing carried out, the significance value obtained is 0.000 . It can be concluded that this regression model can be used because it has a significance value below 0.05 . For the $F$ value, the value is 63.873. When compared with the F table for this study which has a value of 3.09 , which means $\mathrm{F}$ count $i \mathrm{~F}$ table, then $H_{o} 4$ is rejected and $H_{a} 4$ is accepted. This is following Muhammad Aqsath Faza's research in 2018 which is the basis of this research that e-WOM has a positive effect on purchase interest mediated by brand image. In addition, research conducted by Anisa Septaria Residona in 2019 also proved that e-WOM has a significant effect on purchase intention mediated by brand image.

Based on the calculation results obtained from the application of the Sobel Test Calculator for Significance of Mediation, the $t$ value of 6.259 is greater than the $t$ table with a significance level of 0.05 , namely 1.983 . Figure 1 shows that the twotailed probability value is 0,$000 ; 0.05$, it can be concluded that the Somethinc brand image significantly mediates the effect of electronic word of mouth on TikTok on the purchase intention of Somethinc skincare products. 
Table 1: ANOVA Electronic Word of Mouth on Purchase Intention

\begin{tabular}{lccccc}
\hline Model & $\begin{array}{l}\text { Sum of } \\
\text { Squares }\end{array}$ & df & $\begin{array}{l}\text { Mean } \\
\text { Square }\end{array}$ & F & Sig. \\
\hline Regression & 555,956 & 1 & 555,956 & & \\
Residual & 915,354 & 98 & 9,340 & 59,522 & .000 \\
Total & $1,471,310$ & 99 & & & \\
\hline
\end{tabular}

Source: Author

Table 2: Add caption

\begin{tabular}{lrcccc}
\hline Model & $\begin{array}{l}\text { Sum of } \\
\text { Squares }\end{array}$ & df & $\begin{array}{l}\text { Mean } \\
\text { Square }\end{array}$ & F & Sig. \\
\hline Regression & 700,799 & 1 & 700,799 & & \\
Residual & 789,791 & 98 & 8,059 & 86,958 & .000 \\
Total & $1,490,590$ & 99 & & & \\
\hline Source: Author
\end{tabular}

Source: Author

Table 3: ANOVA Brand Image on Purchase Intention Model

\begin{tabular}{lrrccc}
\hline Model & $\begin{array}{l}\text { Sum of } \\
\text { Squares }\end{array}$ & df & $\begin{array}{l}\text { Mean } \\
\text { Square }\end{array}$ & F & Sig. \\
\hline Regression & 804,000 & 1 & 804,000 & & \\
Residual & 667,310 & 98 & 6,809 & 118,074 & .000 \\
Total & $1,471,310$ & 99 & & & \\
\hline
\end{tabular}

Source: Author

Table 4: ANOVA Electronic Word of Mouth on Purchase Intention by Brand Image

\begin{tabular}{lrrccc}
\hline Model & $\begin{array}{l}\text { Sum of } \\
\text { Squares }\end{array}$ & df & $\begin{array}{l}\text { Mean } \\
\text { Square }\end{array}$ & F & Sig. \\
\hline Regression & 836,293 & 2 & 418,147 & & \\
Residual & 635,017 & 97 & 6,547 & 63,873 & .000 \\
Total & $1,471,310$ & 99 & & & \\
\hline
\end{tabular}

Source: Author 


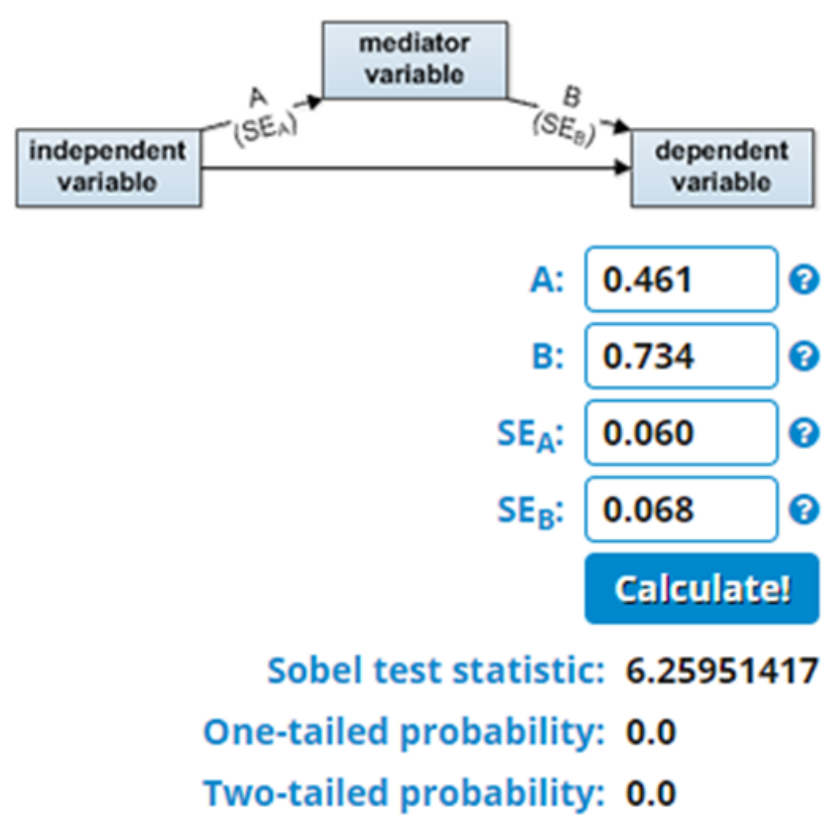

Figure 1: Sobel Test

\section{CONCLUSION}

This research was conducted to analyze the influence of electronic word of mouth on TikTok on purchase intention of Somethinc skincare products through the brand image of respondents; be at least 18 years old, are a TikTok user, and know and have never bought Somethinc skincare products. This research provides new insights that can be used by industry and companies, especially those in the beauty industry to answer problems regarding the electronic word of mouth on TikTok which can affect purchase intention through brand image. Based on the results of the data analysis conducted, it is known that the results of data analysis state that the four hypotheses of this study are accepted. With this, the researcher can conclude that there is an influence between e-WOM in TikTok on purchase intention of Somethinc skincare products, influence between e-WOM on TikTok on Somethinc brand image, influence between Somethinc brand image on purchase intention of Somethinc skincare product, and influence between Electronic word of mouth on TikTok towards purchase intention of Somethinc skincare products through brand image.

Based on these conclusions, the researcher has several suggestions that can be used by the company and further research. These suggestions are Somethinc is expected to be able to increase the positive influence of e-WOM by concentrating more and actively answering questions or complaints raised by consumers on TikTok to create positive conversations to influence brand image and purchase intention. Somethinc is also expected to develop a unique selling proposition so that consumers can differentiate their products from competitors so that they can increase brand image and purchase intention. In addition, Somethinc is expected to maintain and improve the quality of its skincare products according to the content promoted in its advertisements, so that it can increase a good brand image and purchase intention of Somethinc's skincare products itself. The next researcher can then develop this research by making comparisons using other platforms that contain an electronic word of mouth, the use of a larger sample, and other variables that can also affect purchase intention, such as other marketing strategies besides electronic word of mouth, the use of others variables such as brand awareness, brand trust, and others.

\section{References}

ACNielson, 2007. Trust in Advertising: A Global Nielsen Consumer Report. October.

Beautyjournal.id, 2020. Viral Produk Peeling The Ordinary di TikTok, Berikut 5 Rekomendasi Peeling Wajah Lainnya yang tak Kalah Menarik:.

URL: https://journal.sociolla.com/beauty/ rekomendasi-peeling-wajah-viral-di-tiktok

Brown, J. J., Reingen, P. H., 1987. Social Ties and Word-of-Mouth Referral Behavior. Journal of Consumer Research 14 (3), 350-362.

URL: http://www.jstor .org/stable/2489496

Dateportal.com, 2020. Hootsuite (We Are Social): Indonesian Digital Report. URL: digital-2020-indonesia https://datareportal. com/reports/

Elseidi, R., El-Baz, D., 2016. Electronic word of mouth effects on consumers' brand attitudes, brand image and purchase intention: an empirical study in Egypt.

Forums, O., Lists, D., 2020. Tiga Merek Skincare Lokal yang Laris di E-Commerce.

URL: https://cantik.tempo.co/read/1386897/ tiga-merek-skincare-lokal-yang-laris-di-e-commerce/ full $\{\&\}$ view=ok

Hair, J. F., 2014. Multivariate Data Analysis A Global Perspective Seventh Edition. Pearson.

Hennig-Thurau, T., Gwinner, K. P., Walsh, G., Gremler, D. D., 2004. Electronic word-of-mouth via consumer-opinion platforms: What motivates consumers to articulate themselves on the Internet? Journal of Interactive Marketing 18 (1).

URL: http://doi.org/10.1002/dir.10073

DOI: $10.1002 / \operatorname{dir} .10073$

Indiemarket.news, 2020. Somethinc, Brand Komestik Lokal dengan Kualitas Internasional.

URL: https: //indiemarket .news/somethinc-brand-kosmetik-1

Industri.kontan.co.id, 2019. Pasar Produk Perawatan Kulit Punya Potensi Berkembang:.

URL:

https://industri.kontan.co.id/news/ pasar-produk-perawatan-kulit-punya-potensi-berkembang

Jalilvand, M. R., Samiei, N., 2012. The Effect of Electronic Word of Mouth on Brand Image and Purchase Intention: An empirical study in the automobile industry in Iran. Marketing Intelligence \& Planning 30 (4).

Katadata.co.id, 2020. TikTok Telah Diundur Lebih dari 2 Miliar Kali di Dunia:. URL: https : //databoks . katadata.co.id/datapublish/2020/09/ 21/tiktok-telah-diunduh-lebih-dari-2-miliar-kali-di-dunia

Kementerian Perindustrian dan Perdagangan, 2020. Perubahan Gaya Hidup Dorong Industri Kosmetik:.

URL: https://kemenperin.go.id/artikel/21460/ Perubahan-Gaya-Hidup-Dorong-Industri-Kosmetik

Kinnear, T. C., 1995. Riset Pemasaran. Alih Bahasa. Erlangga, Yohanna Lamarto; Jilid II. . Jakarta.

Loreal-finance.com, 2019. L'oreal Annual Report 2019. URL: https : //www. loreal-finance.com/system/files/2020-03/ LOREAL\{_\}2019\{_\}Annual\{_\}Report\{_\}3.pdf

Neuman, W. L., 2014. Social Research Methods: Qualitative and Quantitative Approaches. Pearson, New York.

Ramadhanny, F., 2019. Jenis Video TikTok Paling Favorit. URL: https://inet.detik.com/cyberlife/d-4785023/ 5-jenis-video-tiktok-paling-favorit

Rowley, J., 2001. Remodelling marketing communications in an Internet environment. Internet Research 11 (3), 203-212. 
Sekaran, U., 2011. Research Method for Business. Salemba Empat, Edisi I \& II. Jakarta.

Sensortower.com, 2020. Top Apps Worldwide for August 2020 by Downloads:. URL: https://sensortower.com/blog/ top-apps-worldwide-august-2020-by-downloads

Wang, J.-J., Wang, L.-Y., Wang, M., 2018. Understanding the effects of eWOM social ties on purchase intention: A moderated mediation investigation.
Electronic Commerce Research and Applications 28, 54-62.

URL: http://doi .org/10.1016/j.elerap.2018.01.011

Wolipop.detik.com, 2020. Review Skincare di TikTok, Cewek Gen Z Bikin Skincare Ini Jadi Viral:

URL: https ://wolipop.detik.com/makeup-and-skincare/ d-4922397/review-skincare-di-tiktok-cewek-gen-z-bikinskincare-ini-jadi-viral 